\title{
POPULATION HEALTH ASPECTS OF MOSQUITO-BORNE DISEASE IN NEW SOUTH WALES
}

Stephen Doggett

Department of Medical Entomology

Institute of Clinical Pathology and Medical Research, Westmead

Human pathogens transmitted by mosquitoes pose a significant threat to population health in New South Wales. Within the State, there is annual activity of Ross River virus and Barmah Forest virus, occasional activity from Kunjin virus and Sindbis virus, and rare epidemics of Murray Valley encephalitis virus. For the traveller, dengue and malaria are constant threats. The focus of this article will be the mosquito-borne viruses (the 'arboviruses'), including the factors that influence their activity in New South Wales, how they affect the community, and the future threats they pose to population health in the State.

\section{ARBOVIRUS ACTIVITY IN NEW SOUTH WALES}

Arbovirus activity is dependent on numerous factors: the availability of water (especially rainfall and tidal amplitude), temperature, mosquito vectors, reservoir hosts, past activity, geography, and population demographics.

Mosquitoes require water to breed; more water means more mosquitoes and disease. Mosquito activity is linked to temperature and therefore more cases of arbovirus infection occur in the warmer north of the State with its longer mosquito season. Competent vectors (that is, mosquitoes able to transmit the virus) are present in most of New South Wales.

Arboviruses cycle naturally between mosquitoes and vertebrate hosts. The distribution and movements of the host will also limit the virus distribution. For example, waterbirds, which are the natural hosts of Murray Valley encephalitis virus, do not disperse to the coast and hence the virus does not occur there.

In any year, arbovirus activity also depends on immunity in the population. Recent epidemics mean that levels of antibodies are high, which confers some protection to both natural hosts and humans. Conversely, little activity means antibodies are low and the population is highly susceptible.

The geography of New South Wales has defined 3 broad 'virogeographic' zones for arbovirus activity: the inland, tablelands and coast. The inland has low and inconsistent rainfall, with infrequent flooding resulting in occasional large outbreaks of activity. The irregular rainfall means that seasonal activity is highly variable. Much of the ongoing activity has arisen through human land uses, particularly that of irrigation, which often result in massive mosquito breeding.

The tablelands have little vector breeding and arbovirus activity, and many of the cases in this zone are probably acquired elsewhere. The Great Dividing Range, which forms the tablelands, provides a climatic and physical barrier that helps to maintain moisture levels along the coast and restrict the distribution and movements of certain natural hosts such as waterbirds.

On the coast, rainfall is more consistent and mosquito activity more regular. Tidal inundation also promotes breeding of mosquitoes in the saltmarshes. A combination of high tides and heavy rainfall has resulted in some of the largest outbreaks in the State. This includes the Barmah Forest virus epidemics of 1995 (south coast) and 2001 (mid-north coast), ${ }^{1,2}$ and the combined Ross River virus and Barmah Forest virus epidemic of 2003 (northern rivers). ${ }^{3}$ Freshwater breeding mosquitoes may breed in large numbers after rain, with arbovirus activity ensuing. The Ross River virus outbreaks of 1996 (northern rivers) and 1997 (western Sydney), ${ }^{4,5}$ and the Barmah Forest virus cases in 2002 (western Sydney), ${ }^{6}$ were all probably the result of transmission via freshwater mosquitoes.

Cities, particularly Sydney, have lost large areas of natural habitat along with the native fauna. The lack of hosts means that there is little urban arbovirus transmission, except on the outskirts of the city. Thus, most notifications from Sydney (except some from the outskirts) have been acquired elsewhere.

\section{ARBOVIRUS SURVEILLANCE IN NEW SOUTH WALES}

The methods employed for monitoring arbovirus activity within the State include mosquito surveillance, the use of sentinel animals, and the notification of human disease. Mosquito populations are routinely monitored at up to 30 locations across the State, through the months of November to April, in order to detect unusual densities that may indicate increased arbovirus activity. At inland monitoring locations, the mosquitoes are also tested for the presence of virus. Sentinel chickens located at inland locations are bled weekly during the mosquito season to detect the transmission of Murray Valley encephalitis virus and Kunjin virus. NSW Health funds these activities and the results are publicly available on the NSW Arbovirus Surveillance and Mosquito Monitoring Program website at www.arbovirus.health.nsw.gov.au.

Human infectious diseases are reported to the NSW Department of Health's Notifiable Diseases Database, with most arbovirus cases notified between December and the following May. However, information derived from this database (such as in Tables 1-2 and Figures 1-4) does have some limitations. There is no distinction between presumptive cases (single positive IgM serology) and confirmed cases (fourfold or greater increase in antibody titre between acute and convalescent sera), while the patient location is recorded as the residential address, 


\section{TABLE 1}

NOTIFICATIONS OF MOSQUITO-BORNE DISEASES, NEW SOUTH WALES, 1995-96 TO 2002-03

\begin{tabular}{|c|c|c|c|c|c|c|c|c|c|}
\hline Year & 1995-96 & $1996-97$ & $1997-98$ & 1998-99 & 1999-00 & 2000-01 & 2001-02 & 2002-03 & Total \\
\hline Ross River virus & 939 & 1537 & 344 & 1211 & 736 & 773 & 218 & 456 & 6214 \\
\hline Barmah Forest virus & 155 & 188 & 118 & 242 & 188 & 375 & 404 & 428 & 2098 \\
\hline Sindbis virus & 0 & 0 & 0 & 3 & 3 & 4 & 7 & 7 & 24 \\
\hline Murray Valley Encephalitis virus ${ }^{1}$ & 0 & 0 & 1 & 0 & 0 & 0 & 0 & 0 & 1 \\
\hline Kunjin virus & 1 & 0 & 0 & 0 & 0 & 1 & 0 & 0 & 2 \\
\hline Kokobera virus & 0 & 0 & 1 & 0 & 0 & 0 & 0 & 0 & 1 \\
\hline Dengue viruses ${ }^{2}$ & 15 & 18 & 36 & 32 & 23 & 25 & 66 & 73 & 288 \\
\hline $\begin{array}{l}\text { Arbovirus notifications not } \\
\text { otherwise specified }\end{array}$ & 4 & 2 & 0 & 1 & 1 & 3 & 1 & 0 & 12 \\
\hline Malaria $^{2}$ & 133 & 191 & 163 & 160 & 205 & 175 & 147 & 100 & 1274 \\
\hline Total & 1247 & 1936 & 663 & 1649 & 1156 & 1356 & 843 & 1064 & 9914 \\
\hline
\end{tabular}

1 The 1 case of Murray Valley Encephalitis virus was presumed to be acquired outside of NSW.

2 Both Dengue and Malaria are acquired outside of NSW.

Source: Notifiable Diseases Database, Communicable Diseases Branch, NSW Department of Health; and GODSEND (Graphical Online Data Surveillance and Evaluation of Notifiable Diseases), Centre for Epidemiology and Research, NSW Department of Health.

\section{TABLE 2}

NOTIFICATIONS AND RATES OF ROSS RIVER VIRUS DISEASE AND BARMAH FOREST VIRUS DISEASE BY AREA HEALTH SERVICE GROUPED ACCORDING TO VIROGEOGRAPHIC REGION, NEW SOUTH WALES, JANUARY 1995 TO FEBRUARY 2004

\begin{tabular}{|c|c|c|c|c|c|}
\hline & $\begin{array}{l}\text { Area health } \\
\text { service }\end{array}$ & $\begin{array}{c}\text { No. RRV } \\
\text { disease cases }\end{array}$ & $\begin{array}{c}\text { Crude rate per } \\
100,000 \text { per annum }\end{array}$ & $\begin{array}{c}\text { No. BFV } \\
\text { disease cases }\end{array}$ & $\begin{array}{c}\text { Crude rate per } \\
100,000 \text { per annum }\end{array}$ \\
\hline \multirow[t]{6}{*}{ Sydney } & CS & 41 & 0.9 & 9 & 0.2 \\
\hline & NS & 148 & 2.2 & 15 & 0.2 \\
\hline & WS & 109 & 1.8 & 11 & 0.2 \\
\hline & WEN & 181 & 6.5 & 8 & 0.3 \\
\hline & SWS & 70 & 1.0 & 7 & 0.1 \\
\hline & SES & 79 & 1.2 & 14 & 0.2 \\
\hline \multirow[t]{6}{*}{ Coastal } & NR & 998 & 42.9 & 747 & 31.8 \\
\hline & MNC & 803 & 34.8 & 984 & 42.1 \\
\hline & HUN & 785 & 16.4 & 167 & 3.4 \\
\hline & $\mathrm{CC}$ & 316 & 12.6 & 36 & 1.3 \\
\hline & ILL & 275 & 9.0 & 114 & 3.7 \\
\hline & SA & 230 & 14.1 & 218 & 13.5 \\
\hline \multirow[t]{5}{*}{ Inland } & NE & 527 & 33.1 & 47 & 3.0 \\
\hline & MAC & 440 & 47.5 & 18 & 1.9 \\
\hline & MW & 202 & 13.5 & 10 & 0.7 \\
\hline & GM & 928 & 40.3 & 51 & 2.2 \\
\hline & FW & 391 & 88.5 & 35 & 8.0 \\
\hline \multicolumn{2}{|l|}{ All Sydney } & 628 & 1.9 & 64 & 0.2 \\
\hline \multicolumn{2}{|l|}{ All Coastal } & 3,407 & 20.4 & 2,266 & 13.5 \\
\hline \multicolumn{2}{|l|}{ All Inland } & 2,488 & 31.8 & 161 & 2.4 \\
\hline \multicolumn{6}{|c|}{$\begin{array}{l}\text { CS }=\text { Central Sydney, NS = Northern Sydney, WS }=\text { Western Sydney, WEN = Wentworth, SWS = South West Sydney, SES = South } \\
\text { Eastern Sydney, NR = Northern Rivers, MNC = Mid-North Coast, HUN = Hunter, CC = Central Coast, ILL = Illawarra, SA = Southern } \\
\text { Area, NE = New England, MAC = Macquarie, MW = MidWest, GM = Greater Murray, FW = Far West } \\
\text { RRV = Ross River virus, BFV = Barmah Forest virus }\end{array}$} \\
\hline \multicolumn{6}{|c|}{$\begin{array}{l}\text { Source: Notifiable Diseases Database, Communicable Diseases Branch, NSW Department of Health; and GODSEND (Graphical } \\
\text { Online Data Surveillance and Evaluation of Notifiable Diseases), Centre for Epidemiology and Research, NSW } \\
\text { Department of Health. }\end{array}$} \\
\hline
\end{tabular}


which may not be where the infection occurred. It is likely that the latter information is more reliable in country areas where the viruses are endemic and most cases occur. The reported notification date is either the date of disease onset or the date of specimen collection, whichever is earlier. As the date of onset is not recorded in the vast majority of notifications (as case follow-up would be required to establish disease onset), the specimen collection date is mostly used. The incubation period of most arboviruses averages 7-10 days. Assuming a further delay of 5 days before the patient consults their general practitioner and has blood taken for testing, the notification date can be 2 weeks or longer after the patient was bitten by the vector mosquito.

\section{NOTIFICATIONS OF MOSQUITO-BORNE DISEASE IN NEW SOUTH WALES}

Table 1 lists the notifications of mosquito-borne diseases in New South Wales for the financial years July 1995 to June 2003. The dengue and malaria notifications are included to demonstrate the significant risks to the traveller. Excluding the latter 2, there were a total of 8,352 cases of arbovirus infections notified during this period of 8 seasons, with an average of 1,044 cases per season. A brief discussion of the 3 most significant locallytransmitted arboviruses follows.

\section{Ross River virus}

Ross River virus is the most common arbovirus to infect humans within Australia. The disease is typified by rash, fever, arthralgia and arthritis. The disease occurs in all states, although notification rates are greater in the northern states. In New South Wales, there were 6,214 cases from July 1995 to June 2003 (Table 1). The virus is endemic in both coastal and inland regions, with the occasional disease outbreak in western Sydney. ${ }^{5,7}$ Within the State, the north coast produces the greatest number of cases (Table 2), although the far west has the highest notification rates; generally the more rural the area the greater the number of cases and the higher the rate. The majority of cases occur in people aged 20 to 60 (Figure 1), with no significant difference between the sexes.

Notifications of Ross River virus cases peak very late in the season (Figure 2), with many still being reported in May when mosquito populations are well on the decline. It is difficult to determine the reason for this, but perhaps with the declining numbers people become less vigilant in their personal protection measures against mosquitoes.

\section{FIGURE 1}

ROSS RIVER VIRUS DISEASE NOTIFICATIONS BY AGE AND SEX, NEW SOUTH WALES, JANUARY 2000 TO FEBRUARY 2004

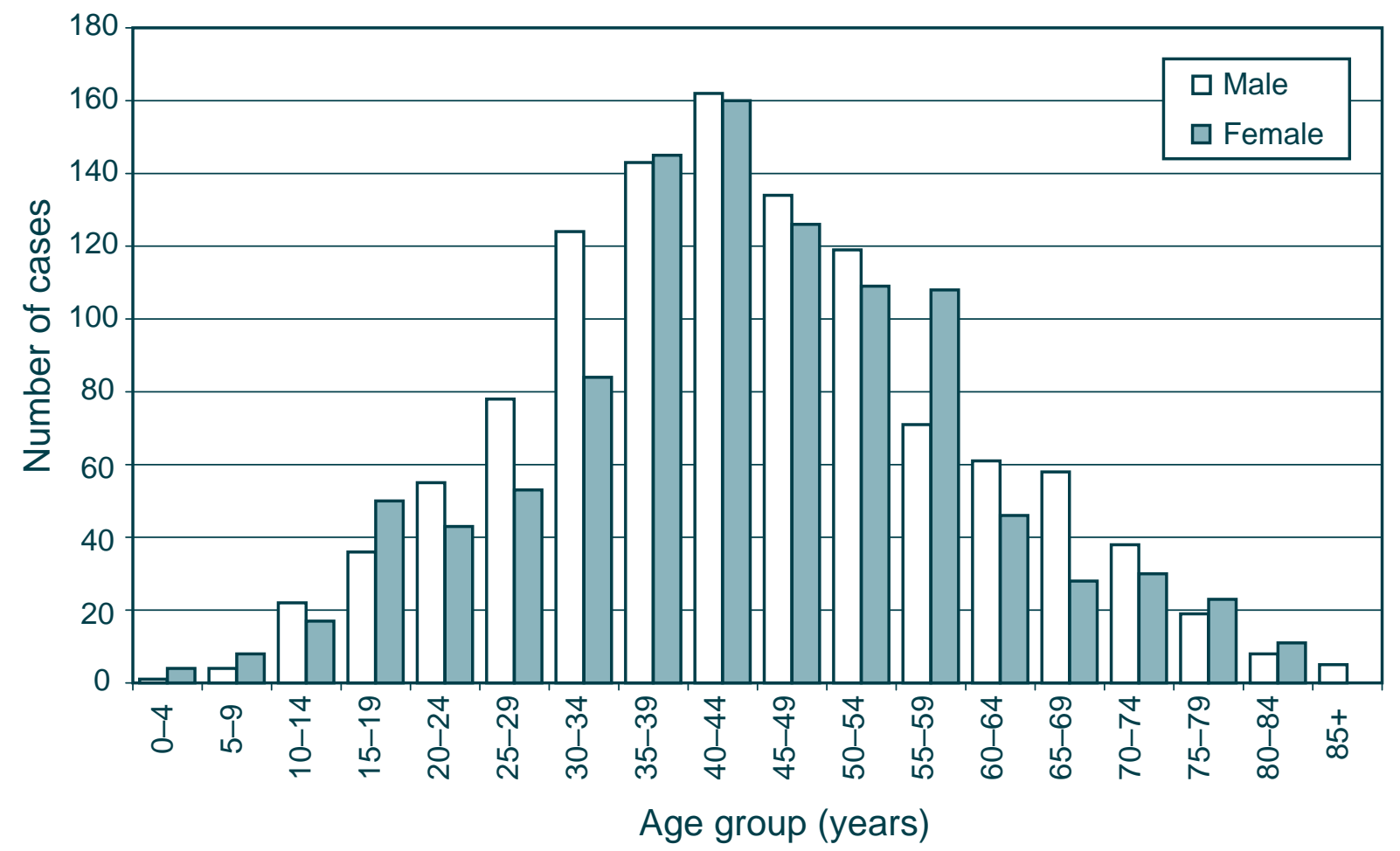

Source: Notifiable Diseases Database, Communicable Diseases Branch, NSW Department of Health; and GODSEND (Graphical Online Data Surveillance and Evaluation of Notifiable Diseases), Centre for Epidemiology and Research, NSW Department of Health. 


\section{FIGURE 2}

NOTIFICATIONS OF ROSS RIVER VIRUS DISEASE AND BARMAH FOREST VIRUS DISEASE BY MONTH, NEW SOUTH WALES, JANUARY 1995 TO FEBRUARY 2004

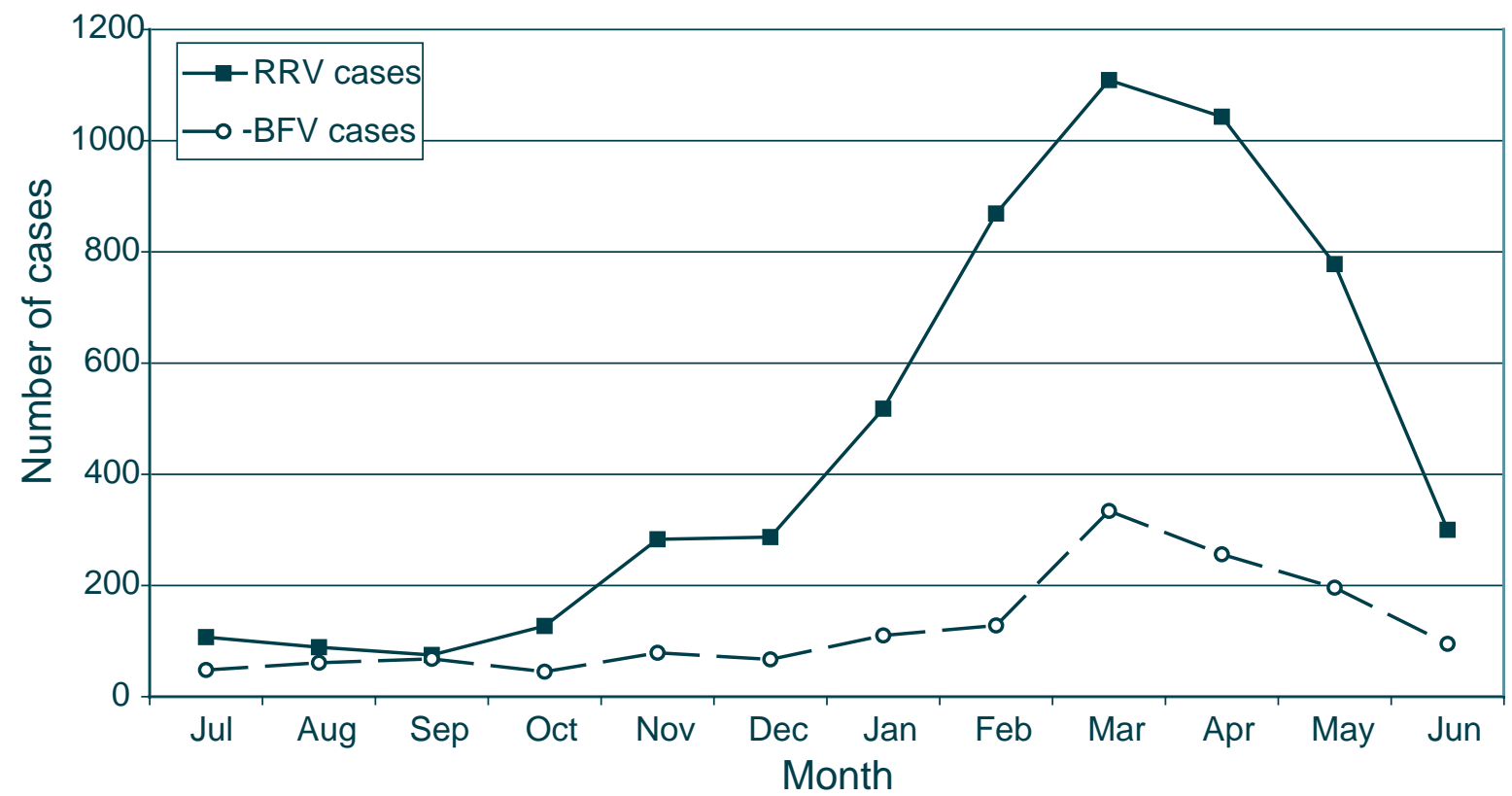

Source: Notifiable Diseases Database, Communicable Diseases Branch, NSW Department of Health; and GODSEND (Graphical Online Data Surveillance and Evaluation of Notifiable Diseases), Centre for Epidemiology and Research, NSW Department of Health.

\section{FIGURE 3}

SEASONAL NOTIFICATIONS OF ROSS RIVER VIRUS DISEASE AND BARMAH FOREST VIRUS DISEASE, NEW SOUTH WALES, JANUARY 1995 TO FEBRUARY 2004

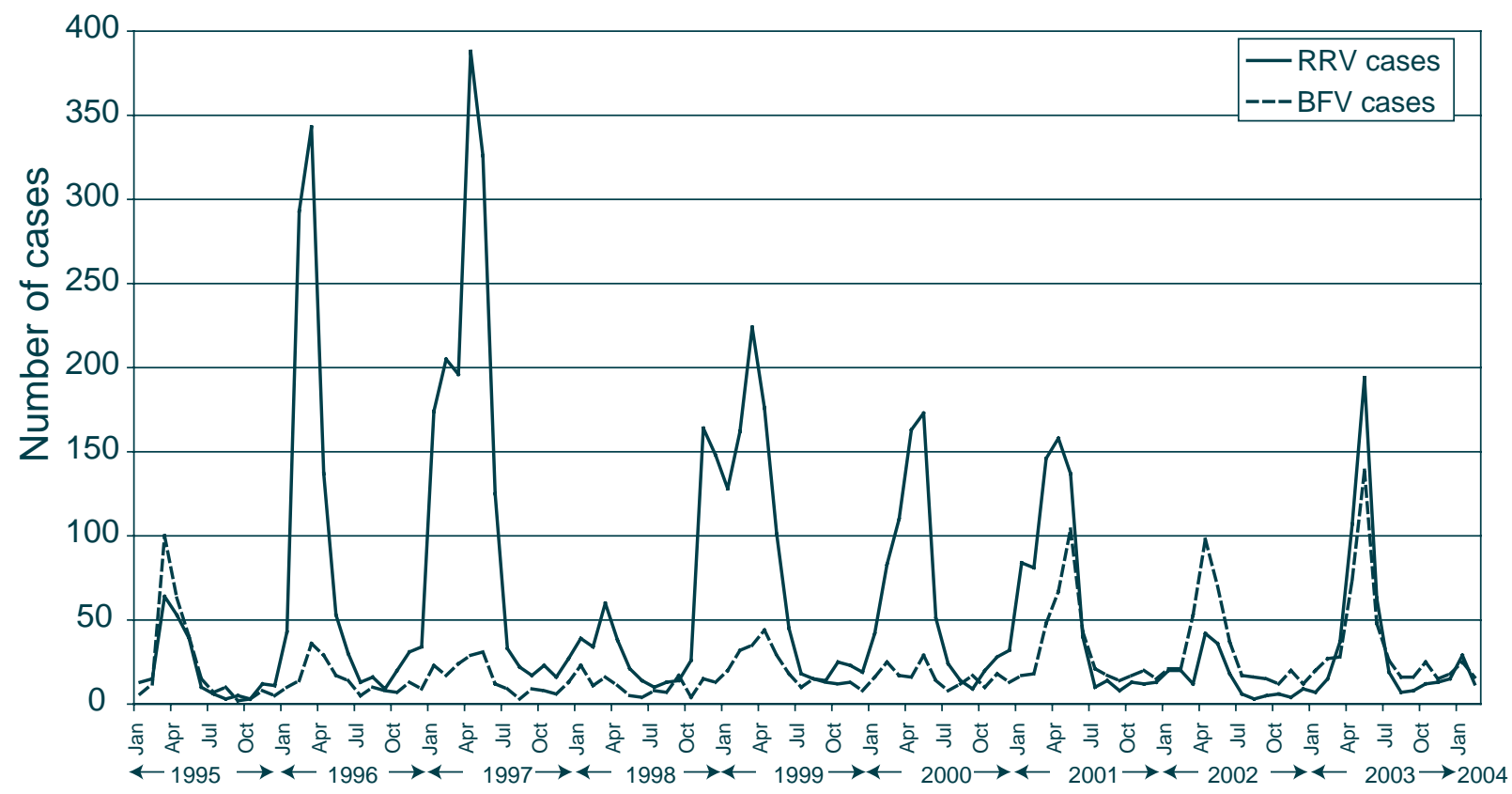

Date

Source: Notifiable Diseases Database, Communicable Diseases Branch, NSW Department of Health; and GODSEND (Graphical Online Data Surveillance and Evaluation of Notifiable Diseases), Centre for Epidemiology and Research, NSW Department of Health. 
Activity of the virus and the number of Ross River virus cases is quite variable from season to season (Figure 3) and for rural areas there is annual endemic activity. Major outbreaks are associated with extreme rainfall, such as the 1983-84 epidemic, which was widespread across the inland with 1,196 cases. $^{8}$ During outbreaks, notification rates can be extraordinarily high. During March 1996, rates of 1006.2 per 100,000 were recorded in the Far West Area Health Service. Occasionally outbreaks can be very localised and intense. The outbreak in western Sydney during 1997 resulted in 69 cases over a small geographic area. ${ }^{5}$ It would appear that these types of outbreaks occur after a considerable time of absence of local activity.

\section{Barmah Forest virus}

Barmah Forest virus shows many similarities to Ross River virus: similar disease symptoms (albeit less prolonged), similar seasonal activity (Figure 2, but note this is unlike Queensland, which has a secondary peak of Barmah Forest virus in November), ${ }^{9}$ similar age group affected (Figure 4), and similar male-to-female disease ratio (Figure 4). The big difference for New South Wales is that Barmah Forest virus appears to be largely confined to the coastal region. Most notifications are from the coast (Table 2) and only 1 instance of Barmah Forest virus has been isolated from inland-trapped mosquitoes (collected from Menindee in 1993) and processed by the NSW Arbovirus Surveillance Program. ${ }^{10}$ It is possible that many cases reported from the inland region were acquired from coastal districts. Why the virus is largely confined to this region is not known, but there is evidence to suggest that Culex annulirostris, the main inland arbovirus vector mosquito, is an inefficient vector of Barmah Forest virus. ${ }^{11}$ Currently, the reservoir hosts (that is, the vertebrate hosts involved in endemic arbovirus cycles) are not known, but perhaps the distribution of these is helping to confine activity to the coast.

The seasonal (Figure 3) and spatial activity of Barmah Forest virus is highly variable. On the south coast, there are relatively few cases annually and the disease is largely epidemic in nature, with 1 large outbreak in 1995 with 135 cases. ${ }^{1}$ Many more cases with higher notification rates occur along the north coast, and there have been large recent outbreaks over the 3 consecutive seasons of 2000-01 to $2002-03$. $^{2,3,6}$

Elsewhere in the country, Barmah Forest virus disease shows a similar trend, with most human cases occurring in coastal regions. Likewise, the disease tends to show epidemic patterns in most states. ${ }^{1,12}$

\section{FIGURE 4}

BARMAH FOREST VIRUS DISEASE NOTIFICATIONS BY AGE AND SEX, NEW SOUTH WALES, JANUARY 2000 TO FEBRUARY 2004

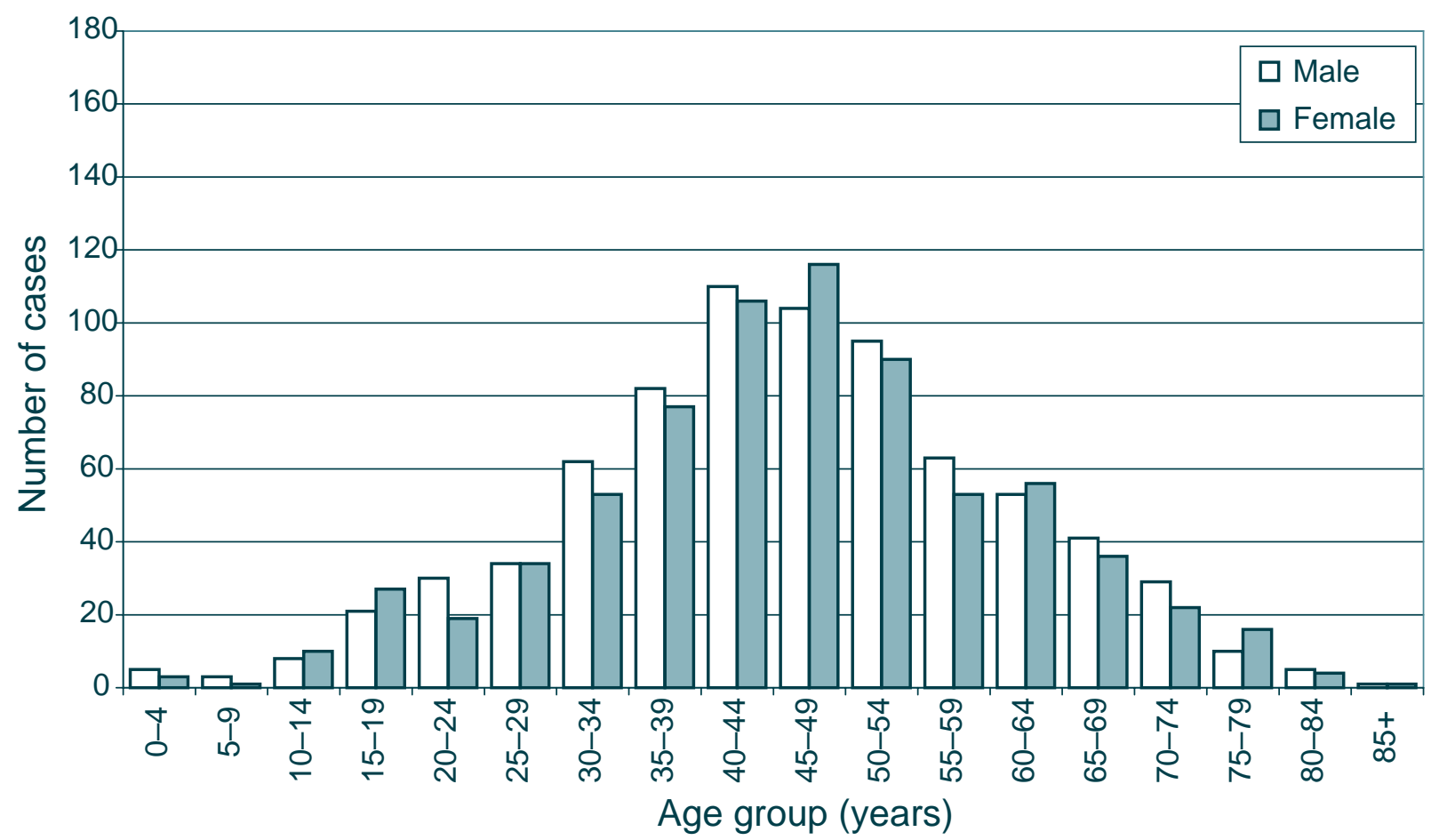

Source: Notifiable Diseases Database, Communicable Diseases Branch, NSW Department of Health; and GODSEND (Graphical Online Data Surveillance and Evaluation of Notifiable Diseases), Centre for Epidemiology and Research, NSW Department of Health. 


\section{Murray Valley encephalitis virus}

Murray Valley encephalitis virus is one of the most important arboviruses as the disease has a high fatality rate and many survivors are left with severe permanent neurological damage. The virus is endemic in the northwest of Australia where activity occurs in most years. ${ }^{13}$ For the southeast, Murray Valley encephalitis is epidemic, and previous disease activity has followed 2 wet years. ${ }^{14}$ Past outbreaks in New South Wales have occurred in 1917 (70 cases), 1918 (49 cases), 1925 (10 cases), 1951 (10 cases), 1956 ( 3 cases) and 1974 (5 cases). ${ }^{14}$ The last outbreak involved some 58 cases Australia-wide with 13 deaths, and the majority were from the Murray Valley. The cases within New South Wales were widely dispersed both temporally and spatially over a 10 -week period from the first to the last, with cases from Albury in the east to Broken Hill in the west. In 2001, the virus was widely active along the Darling River, ${ }^{2}$ however, no human disease cases were reported. More recently in late 2003, there was some activity at Menindee, ${ }^{15}$ and again no cases were recognised.

\section{POTENTIAL THREATS TO POPULATION HEALTH IN NEW SOUTH WALES}

Since notifications began in 1991, New South Wales has experienced a period of exceptionally low rainfall, with the 1990s being the driest recorded decade. This suggests that arbovirus activity has been well below normal. A return to regular rainfall patterns may see a return to higher levels of activity in inland areas of the State, as there has been no epidemic Murray Valley encephalitis since 1974, and on the south coast, as there has been little arbovirus activity there since the 1995 Barmah Forest virus outbreak.

Physical changes to the environment through human endeavours may lead to more mosquitoes and arbovirus activity. For example, a recent trend has been to construct wetlands as a means of dealing with stormwater and wastewater. If these wetlands are not constructed to minimise vector breeding or not maintained appropriately, then mosquito production may become a significant issue, particularly for inland communities. ${ }^{16}$ Likewise, the reestablishment of water flows to major river systems for environmental protection may result in increased flooding and enhanced disease activity.

As less land is available for development, especially along the coast, there is pressure on local councils to approve the building of residential or industrial estates close to problematic mosquito areas, especially saltmarshes. Adequate 'buffer zones' need to be defined to reduce the disease risk to the community.

A constant threat is the introduction of exotic vector mosquitoes, especially the dengue vector Aedes albopictus. If introduced, this species has the potential to become established in urban communities across most of southern Australia and dramatically extend the current dengue receptive zone. Government agencies must remain vigilant and adequately resourced to keep this species out and to eliminate it if introduced.

\section{CONCLUSION}

Mosquito-borne viruses pose a significant current and potential threat to the population health of New South Wales. Reduction in the burden of mosquito-borne disease can only come about through a concerted effort involving a multidisciplinary approach encompassing education, surveillance and mosquito control, and this challenge needs to be met not only by all levels of government but by the community has a whole. Current mosquito education programs target health warnings usually before and at the peak of mosquito breeding, yet most human cases appear to occur in the latter part of the season and health warnings should not be discontinued at this time.

\section{ACKNOWLEDGEMENTS}

All notification data were obtained from the Notifiable Diseases Database, Communicable Diseases Branch, NSW Department of Health, and GODSEND (Graphical Online Data Surveillance and Evaluation of Notifiable Diseases), Centre for Epidemiology and Research, NSW Department of Health. Mr Mark Bartlett, Manager Surveillance, Communicable Diseases Branch, NSW Department of Health, provided the explanation of the surveillance data. Associate Professor Richard Russell, Department of Medical Entomology, Institute of Clinical Pathology and Medical Research, Westmead, critically reviewed the manuscript.

\section{REFERENCES}

1. Doggett SL, Russell RC, Clancy J, Haniotis J, Cloonan MJ. Barmah Forest virus epidemic on the south coast of New South Wales, Australia, 1994-1995: viruses, vectors, human cases, and environmental factors. J Med Entomol 1999; 36 : 861-8.

2. Doggett S, Clancy J, Haniotis J, Russell RC, Hueston L, Marchetti M, et al. The New South Wales Arbovirus Surveillance and Mosquito Monitoring Program. 2000-2001 Annual Report. Sydney: Department of Medical Entomology, Westmead, 2001.

3. Doggett S, Clancy J, Haniotis J, Russell RC, Hueston L, Marchetti M, et al. The New South Wales Arbovirus Surveillance and Mosquito Monitoring Program. 2002-2003 Annual Report. Sydney: Department of Medical Entomology, Westmead, 2003.

4. Russell RC, Haniotis J, Doggett SL, Clancy J, Cloonan MJ. The New South Wales Arbovirus Surveillance and Mosquito Monitoring Program 1995-1996. Sydney: Department of Medical Entomology, Westmead, 1996.

5. Amin J, Hueston L, Dwyer DE, Capon A. Ross River virus infection in the north-west outskirts of the Sydney basin. Commun Dis Intell 1998; 11: 101-2.

6. Doggett S, Clancy J, Haniotis J, Russell RC, Hueston L, Marchetti M, et al. The New South Wales Arbovirus Surveillance and Mosquito Monitoring Program. 2001-2002 Annual Report. Sydney: Department of Medical Entomology, Westmead, 2002. 
7. Brokenshire T, Symonds D, Reynolds R, Doggett S, Geary M, Russell R. A cluster of locally-acquired Ross River virus infections in outer Western Sydney. NS W Public Health Bull 2000; 11: 132-4.

8. Hawkes RA, Boughton CR, Naim HM, Stallman ND. A major outbreak of epidemic polyarthritis in New South Wales during the summer of 1983-1984. Med J Aust 1985; 143: 330-33.

9. Hills SL, Sheriden JW. The epidemiology of Barmah Forest virus in Queensland. Arbo Res Aust 1997; 7: 95-99.

10. Russell RC, Cloonan MJ, Doggett SL, Clancy J, Haniotis J, Wells P, et al. Surveillance of arboviruses and vectors in NSW, 1993-1996. Arbo Res Aust 1997; 7: 228-34.

11. Ryan PA, Kay BH. Vector competence of mosquitoes (Diptera: Culicidae) from Maroochy Shire, Australia, for Barmah Forest virus. J Med Entomol 1999; 36: 856-60.
12. Passmore J, O'Grady KA, Moran R, Wishart W. An outbreak of Barmah Forest virus disease in Victoria. Commun Dis Intell 2002; 26: 600-4.

13. Broom A, Sturrock K, vanHeuzen B, Lindsay M, Smith D. Seroconversions in sentinel chickens provide an early warning of Murray Valley Encephalitis virus activity in Western Australia. Arbo Res Aust 2001; 8: 43-7.

14. Forbes JA. Murray Valley encephalitis 1974: also the epidemic variance since 1914 and predisposing rainfall patterns. Sydney: Australasian Medical Publishing Company, 1978.

15. The New South Wales Arbovirus Surveillance and Mosquito Monitoring Program website. Menindee Results. Available at www.arbovirus.health.nsw.gov.au/areas/arbovirus/results/ menindee/menindee.htm. Accessed February 2004.

16. Russell RC. Constructed wetlands in Australia: concerns and constraints, compromises and complements for effective mosquito management. Arbo Res Aust 2000; 8: 314-23. 渎

\section{RECENT INCREASES IN THE NOTIFICATION OF BARMAH FOREST VIRUS INFECTIONS IN NEW SOUTH WALES}

\section{Lara Harvey}

NSW Public Health Officer Training Program

NSW Department of Health

\author{
Dominic Dwyer \\ Centre for Infectious Diseases and Microbiology \\ Laboratory Services \\ Institute of Clinical Pathology and Medical Research, \\ Westmead
}

Infection due to Barmah Forest virus (BFV) is an emerging problem in Australia, ${ }^{1}$ with increased numbers of cases being reported. ${ }^{2-5} \mathrm{BFV}$ is a mosquito-borne arbovirus from the Togaviridae family. The virus was first isolated in 1974 from the Barmah State Forest in the Murray Valley region of the Victoria-New South Wales border, ${ }^{6}$ and was first shown to be pathogenic to humans in $1988 .^{7}$ Symptoms of acute human infection may include rash, arthralgia, myalgia, lethargy and fever, ${ }^{3-5,8}$ and are similar to symptoms caused by Ross River virus infection. However, rash is more common and florid, and joint disease is less severe, in BFV disease than in Ross River virus disease. ${ }^{9}$ In a study of BFV cases on the mid-north coast of New South Wales, ${ }^{3}$ over half of all cases reported time off work and an illness that lasted more than 6 months. $\mathrm{BFV}$ disease is therefore associated with a significant burden of illness and is of public health concern. This article describes trends in the notification rates for BFV disease in New South Wales since it was made notifiable in 1991.

\section{METHODS}

Under the NSW Public Health Act 1991, all laboratories must notify suspected cases of BFV infection to the local public health unit. The case definition for a suspected case is a person in whom there are demonstrated specific IgM antibodies to BFV in cerebral spinal fluid or in serum collected within 14 days of onset of symptoms. ${ }^{10}$ Public health unit staff record case details on a confidential statewide database. All cases notified from 1991 to 2003 were geocoded and entered into MapInfo Professional version 7.0 software, ${ }^{11}$ to highlight geographical location of the disease. Only cases notified between 1995 and 2003 were used in the analysis of case characteristics, because of the probability of underreporting and poor data quality in earlier years. ${ }^{12}$ Incidence rates were calculated using the average of the estimated mid-year population for each of the years 1995 to 2003. National data was obtained from the National Notifiable Diseases Surveillance System, ${ }^{13}$ which is available on the Australian Government Department of Health and Ageing website at www.cda.gov.au/surveil.

\section{RESULTS}

For the period 1991-2003 there were 2,527 notifications of BFV infection in New South Wales residents. Before 1995, there were few BFV notifications in the State each year, with 6 cases in 1991, 6 cases in 1992, 25 cases in 1993, and 40 cases in 1994.

In 1995, the number of notifications increased to 271. Of these cases, 122 were resident in the Southern Area Health Service, with 30 per cent of these living in Batemans Bay. ${ }^{2}$

Between 1995 and 2000, there has been continuous BFV activity reported on the north coast of New South Wales, and in the Mid North Coast and Northern Rivers Area Health Services. In 1999, there was a small increase in 